\title{
Vanadium Chloroperoxidase as a Catalyst for Hydrogen Peroxide Disproportionation to Singlet Oxygen in Mildly Acidic Aqueous Environment
}

\author{
Rokus Renirie, ${ }^{\text {a }}$ Christel Pierlot, ${ }^{\mathrm{b}}$ Jean-Marie Aubry, ${ }^{\mathrm{b}}$ Aloysius F. Hartog, ${ }^{\mathrm{a}}$ Hans E. \\ Schoemaker, ${ }^{\mathrm{c}}$ Paul L. Alsters, ${ }^{\mathrm{c}}$ Ron Wever ${ }^{\mathrm{a}, *}$ \\ a Department of Bio-Organic Chemistry, Institute of Molecular Chemistry, University of Amsterdam, Nieuwe \\ Achtergracht 129, 1018 WS Amsterdam, The Netherlands \\ Fax: (+31)-20-5255670, e-mail: rwever@science.uva.nl \\ b LCOM, Equipe "Oxydation et Formulation," UMR CRNS 8009, ENCL, BP 108, 59652 Villeneuve d'Ascq, Cedex, \\ France \\ DSM Life Sciences, Advanced Synthesis and Catalysis, P. O. Box 18, 6160 MD Geleen, The Netherlands
}

\begin{abstract}
Chemiluminescence studies show that the enzyme vanadium chloroperoxidase from the fungus Curvularia inaequalis is a highly efficient catalyst for the production of singlet oxygen from hydrogen peroxide in a mildly acidic aqueous environment, with a maximum turnover frequency of $100 \mathrm{~s}^{-1}$ with respect to $\mathrm{H}_{2} \mathrm{O}_{2}$ consumption. The enzyme studied here can be regarded as a supplementary catalyst to inorganic molybdate, which operates in basic aqueous media. The enzyme system is $10^{3}-10^{4}$ times faster than the molybdate system when compared at their optimal $\mathrm{pH}$. The enzyme is very stable against singlet oxygen, in contrast to heme-containing peroxidases which, due to inactivation by singlet oxygen, only produce a short burst, presumably by oxidation of the labile cofactor. The vanadium chloroperoxidase was compared with vanadium bromoperoxidase from the seaweed Ascophyllum nodosum and was found to be
\end{abstract}

even more stable; it is stable towards a continuous flow of singlet oxygen for at least 1 hour and also it is not inactivated by $500 \mathrm{mM} \mathrm{H}_{2} \mathrm{O}_{2}$. An important difference with vanadium bromoperoxidase is that the vanadium chloroperoxidase is able to effectively use chloride as a cocatalyst $\left(20 \mathrm{~s}^{-1}\right)$ instead of bromide. This offers an important advantage from an application point of view; using chloride, no side products are observed when the chemical trap anthracene-9,10-bis(ethanesulphonate) is fully converted by singlet oxygen into its corresponding endoperoxide. By contrast, when bromide is used, $20 \%$ side product is formed. During the conversion the enzyme remains fully stable for 25,000 turnovers.

Keywords: biocatalysis; singlet oxygen production; vanadium chloroperoxidase (VCPO)

\section{Introduction}

A number of different processes are used to produce singlet oxygen $\left({ }^{1} \mathrm{O}_{2},{ }^{1} \Delta_{\mathrm{g}}\right)$, a reactant that can oxidise various electron-rich organic compounds. ${ }^{[1,2]}$ There are several photochemical processes in which dyes such as rose bengal, methylene blue or porphyrin are irradiated leading to the conversion of normal triplet oxygen to singlet oxygen. ${ }^{[3,4]}$ In addition to these photochemical processes which require irradiation, several "dark" sources exist. For example, one can chemically trap ${ }^{1} \mathrm{O}_{2}$ in the form of naphthalenic endoperoxides, ${ }^{[5]}$ after which these ${ }^{1} \mathrm{O}_{2}$ carriers are thermolysed to release ${ }^{1} \mathrm{O}_{2}$. Simply mixing hypochlorite $\left(\mathrm{ClO}^{-}\right)$with $\mathrm{H}_{2} \mathrm{O}_{2}$ will also produce ${ }^{1} \mathrm{O}_{2},{ }^{[6]}$ however, hypohalites may give rise to unwanted side reactions with organic substrates. Therefore a catalyst is preferred such as molybdate, ${ }^{[7]}$ which disproportionates $\mathrm{H}_{2} \mathrm{O}_{2}$ into ${ }^{1} \mathrm{O}_{2}$ generating a continuous flow of ${ }^{1} \mathrm{O}_{2}$. However, a drawback this system lies in the requirement of alkaline conditions to promote the formation of triperoxomolybdate, $\operatorname{MoO}\left(\mathrm{O}_{2}\right)_{3}{ }^{2-}$, the precursor of ${ }^{1} \mathrm{O}_{2},{ }^{[7]}$ which lowers the synthetic scope of the molybdate-catalyzed "dark" singlet oxygenation. Very recently, we described the use of a heterogeneous lanthanum catalyst for "dark" singlet oxygenation ${ }^{[8]}$ that also works under slightly acidic conditions and the synthetic advantage of this system over the molybdate system was demonstrated. This lanthanum system, however, yields only $45 \%{ }^{1} \mathrm{O}_{2}$ in $\mathrm{H}_{2} \mathrm{O}_{2}$ disproportionation and, in addition, it is significantly slower than the molybdate system. For these reasons there is still an ongoing quest for more efficient catalyst systems that operate at acidic $\mathrm{pH}$ values.

The formation of ${ }^{1} \mathrm{O}_{2}$ under mildly acidic conditions ( $\mathrm{pH} \sim 3-6$ ) by haloperoxidases has been reported and is believed to occur via the mechanism shown in Scheme 1:[9-18] 


$$
\begin{aligned}
& \mathrm{X}^{-}+\mathrm{H}_{2} \mathrm{O}_{2}+\mathrm{H}^{+} \stackrel{\text { enzyme }}{\longrightarrow} \mathrm{HOX}+\mathrm{H}_{2} \mathrm{O} \\
& \mathrm{HOX}+\mathrm{H}_{2} \mathrm{O}_{2} \stackrel{\text { spontaneous }}{\longrightarrow}{ }^{1} \mathrm{O}_{2}+\mathrm{H}_{2} \mathrm{O}+\mathrm{X}^{-}+\mathrm{H}^{+} \text {(2) } \\
& \text { Net reaction } 2 \mathrm{H}_{2} \mathrm{O}_{2} \longrightarrow{ }^{1} \mathrm{O}_{2}+2 \mathrm{H}_{2} \mathrm{O} \\
& (\mathrm{X}=\mathrm{Cl} \text { or } \mathrm{Br})
\end{aligned}
$$

Scheme 1. Putative mechanism for singlet oxygen production by haloperoxidases. ${ }^{[9-18]}$

The haloperoxidases oxidise halides to hypohalous acids (Equation 1) and are named after the most electronegative element they are able to oxidise and hence a chloroperoxidase can oxidise chloride, bromide and iodide, whereas a bromoperoxidase only oxidises bromide and iodide at an appreciable rate. In the case of chloride and bromide, the formed hypohalous acid reacts non-enzymatically with $\mathrm{H}_{2} \mathrm{O}_{2}$ to give ${ }^{1} \mathrm{O}_{2}$ (Equation 2). In this process the halide is regenerated. Accordingly, the process is catalytic in halide provided that no halide is irreversibly lost by side-reactions of HOX. Such side reactions of HOX are minimised by a high $\mathrm{H}_{2} \mathrm{O}_{2}$ concentration in combination with a controlled continuous production of HOX, which is present in a low steady-state concentration. The gradual, controlled HOX release, together with the sub-stoichiometric halide requirement and the acidic processing conditions, make the enzymatic process advantageous to simple mixing of hypochlorite with $\mathrm{H}_{2} \mathrm{O}_{2}$. Production of ${ }^{1} \mathrm{O}_{2}$ has been demonstrated for some heme-containing haloperoxidases. They show, however, only a short burst of ${ }^{1} \mathrm{O}_{2}$ during which these enzymes are inactivated, ${ }^{[13-17]}$ presumably by oxidation of the electron-rich heme moiety by the generated ${ }^{1} \mathrm{O}_{2}$. Moreover, the heme containing haloperoxidases are not stable towards a high concentration of their substrate $\mathrm{H}_{2} \mathrm{O}_{2}$. In contrast, reports of ${ }^{1} \mathrm{O}_{2}$ production by a vanadium bromoperoxidase $^{[18,19]}$ show that this class of enzymes with the more robust vanadate cofactor is much more stable against ${ }^{1} \mathrm{O}_{2}$ and $\mathrm{H}_{2} \mathrm{O}_{2}$, making them more likely candidates for application in organic synthesis. This vanadate $\left(\mathrm{HVO}_{4}{ }^{2-}\right)$ cofactor in these enzymes is covalently attached to a histidine residue, giving rise to a pentacoordinated vanadium atom (Figure 1). ${ }^{[20-23]}$

The resulting trigonal bipyramidal structure is stabilised by several neighbouring amino acid residues. The binding of the peroxide and the formation of the hypohalous acid have been shown to take place at this cofactor $^{[21,25]}$ and it has been shown that this class of enzymes is very stable towards high temperature and organic solvents. ${ }^{[26,27]}$ These stable enzymes have already been shown to have high potential for application in organic synthesis: vanadium bromoperoxidases have been shown to perform enantioselective sulphoxidation $^{[28-31]}$ of a series of compounds of which both $R$ and $S$ enantiomeric excess can be formed, depending on which enzyme is used. ${ }^{[30]}$

A disadvantage of vanadium bromoperoxidase (VBPO) from the seaweed Ascophyllum nodosum is that it experiences slow inactivation during ${ }^{1} \mathrm{O}_{2}$ production. ${ }^{[18]}$ This inactivation is likely to be worse at high $\mathrm{H}_{2} \mathrm{O}_{2}$ concentrations at which this enzyme (at low $\mathrm{pH}$ values) is inactivated by oxidation of a critical histidine. ${ }^{[32,33]}$ These high $\mathrm{H}_{2} \mathrm{O}_{2}$ concentrations (100$1000 \mathrm{mM}$ ) in principle favour the application of haloperoxidases as a ${ }^{1} \mathrm{O}_{2}$ catalyst, since they minimise the
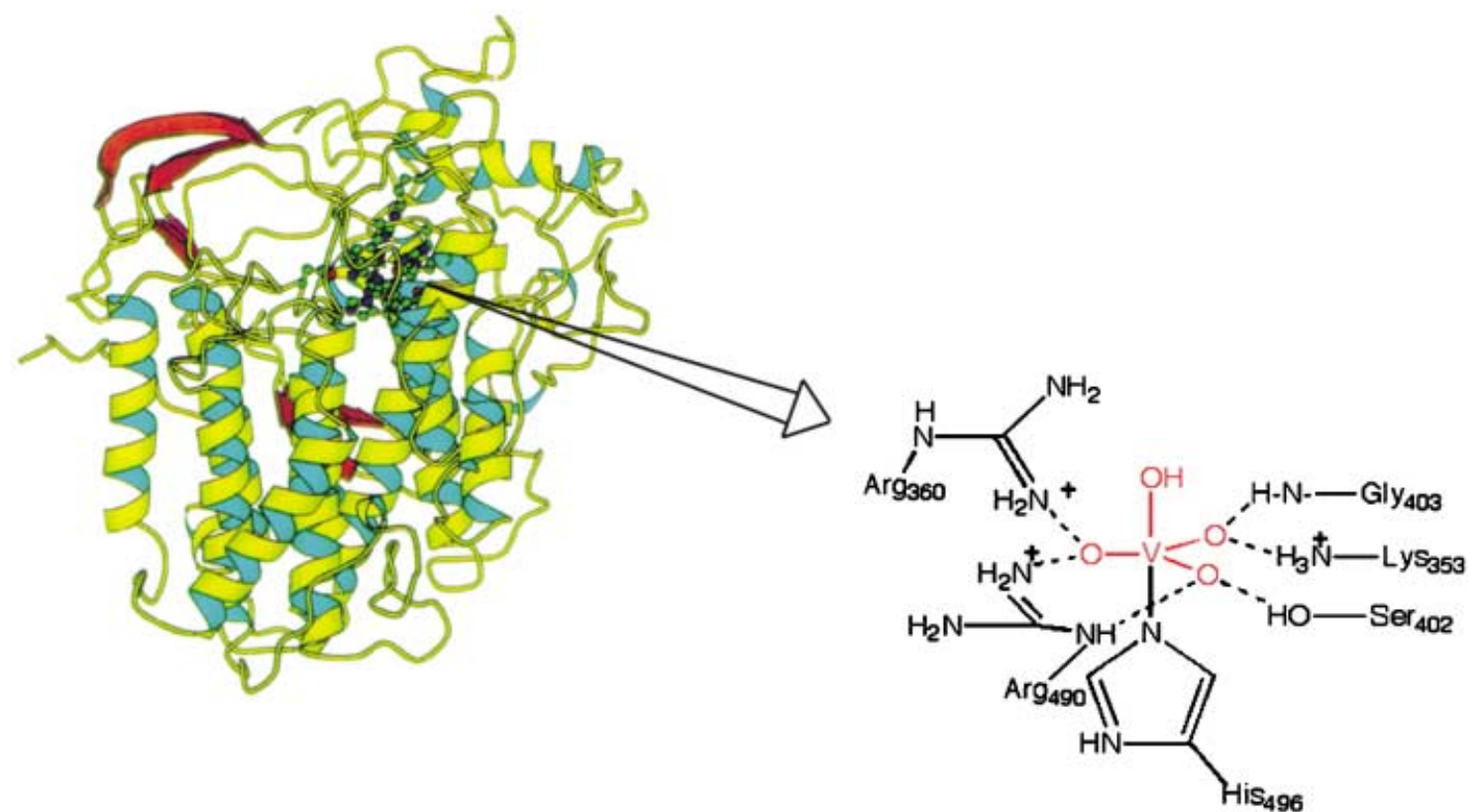

Figure 1. Vanadium chloroperoxidase from Curvularia inaequalis and its active site. The vanadate cofactor is shown in red. This figure was produced with Molscript. ${ }^{[24]}$ 
chance of side reactions of HOX with compounds other than $\mathrm{H}_{2} \mathrm{O}_{2}$. Thus a haloperoxidase with a high resistance towards $\mathrm{H}_{2} \mathrm{O}_{2}$ has an advantage in this application. Vanadium chloroperoxidase (VCPO) from the fungus Curvularia inaequalis ${ }^{[34]}$ is not inhibited by $\mathrm{H}_{2} \mathrm{O}_{2}$, not even at high concentrations. Moreover, the VCPO is able to effectively use chloride instead of bromide which may affect the extent of side reactions of $\mathrm{HOX}$. In addition, the monomeric VCPO is easily expressed as a recombinant protein, ${ }^{[35]}$ which allows easy application in organic conversions.

For these reasons we have investigated ${ }^{1} \mathrm{O}_{2}$ release by VCPO from $C$. inaequalis since it may be a good catalyst for the production of ${ }^{1} \mathrm{O}_{2}$ under mildly acidic conditions and compared it to the ${ }^{1} \mathrm{O}_{2}$ release by VBPO from A. nodosum. For this study the near-infrared emission band at $1268 \mathrm{~nm}$ that is characteristic for ${ }^{1} \mathrm{O}_{2}\left({ }^{1} \Delta_{\mathrm{g}}\right)$ was monitored. We also show the clean conversion of a watersoluble anthracene derivative into the corresponding endoperoxide by VCPO-generated ${ }^{1} \mathrm{O}_{2}$ and discuss the advantages of VCPO over VBPO in this respect.

\section{Results and Discussion}

\section{Singlet Oxygen Production}

In Figure 2 is shown chemiluminescence at $1268 \mathrm{~nm}$ produced by VCPO and VBPO, indicative for ${ }^{1} \mathrm{O}_{2}$ formation. With VCPO as catalyst (left panel), a clear emission at $1268 \mathrm{~nm}$ is observed and the activity even increases after the initial burst. After about 4 minutes the signal drops because of complete conversion of the $\mathrm{H}_{2} \mathrm{O}_{2}$. For VBPO the signal appears almost constant when $2 \mathrm{mM} \mathrm{H}_{2} \mathrm{O}_{2}$ is used (right panel), but using $20 \mathrm{mM}$ $\mathrm{H}_{2} \mathrm{O}_{2}$ a decrease of activity in time is observed (inset right panel). VBPO looses about $35 \%$ of its activity in 30 minutes, whereas VCPO shows no inactivation under these conditions, which gives VCPO a clear advantage over VBPO. It is expected that at lower $\mathrm{pH}$ the inactivation of VBPO will be even worse, especially when higher $\mathrm{H}_{2} \mathrm{O}_{2}$ concentrations are used, since a critical histidine residue is oxidised under those conditions. ${ }^{[32,33]}$ VCPO and VBPO differ in their catalytic properties and therefore the bromide concentration in the VCPO experiment is chosen 200-fold lower than in the VBPO experiment. The VCPO has a much smaller $\mathrm{K}_{\mathrm{M}}$ value for bromide than VBPO. ${ }^{[35]}$ When $0.5 \mathrm{mM}$ bromide is used in an assay, VBPO only exhibits a few percent of its maximal activity whereas VCPO is optimally active at this concentration. Conversely, the optimal concentration for VBPO of $\mathrm{Br}^{-}(100 \mathrm{mM})$ would be inhibitory for the VCPO. ${ }^{[35]}$ The singlet oxygen production was measured at $\mathrm{pH}^{\mathrm{app}} 5.4$ for $\mathrm{VCPO}$ and $\mathrm{pH}^{\mathrm{app}} 6.4$ for $\mathrm{VBPO}$ which correspond to the $\mathrm{pH}$ optima with respect to the oxidation of halides ${ }^{[35,36]}$ and with respect to singlet oxygen production as shown for VBPO by Butler and co-workers ${ }^{[18,19]}$ and for VCPO in the left inset of Figure 2. The similarity of this optimum to the optimum observed for halide oxidation ${ }^{[35]}$ indicates that the catalytic formation of the hypohalous acid, Equation (1), is rate limiting. Apparently the noncatalytic reaction between the hypohalous acid and hydrogen peroxide is much faster, even though it is known to slow down at low $\mathrm{pH}$ values. ${ }^{[6]}$ The similarity of
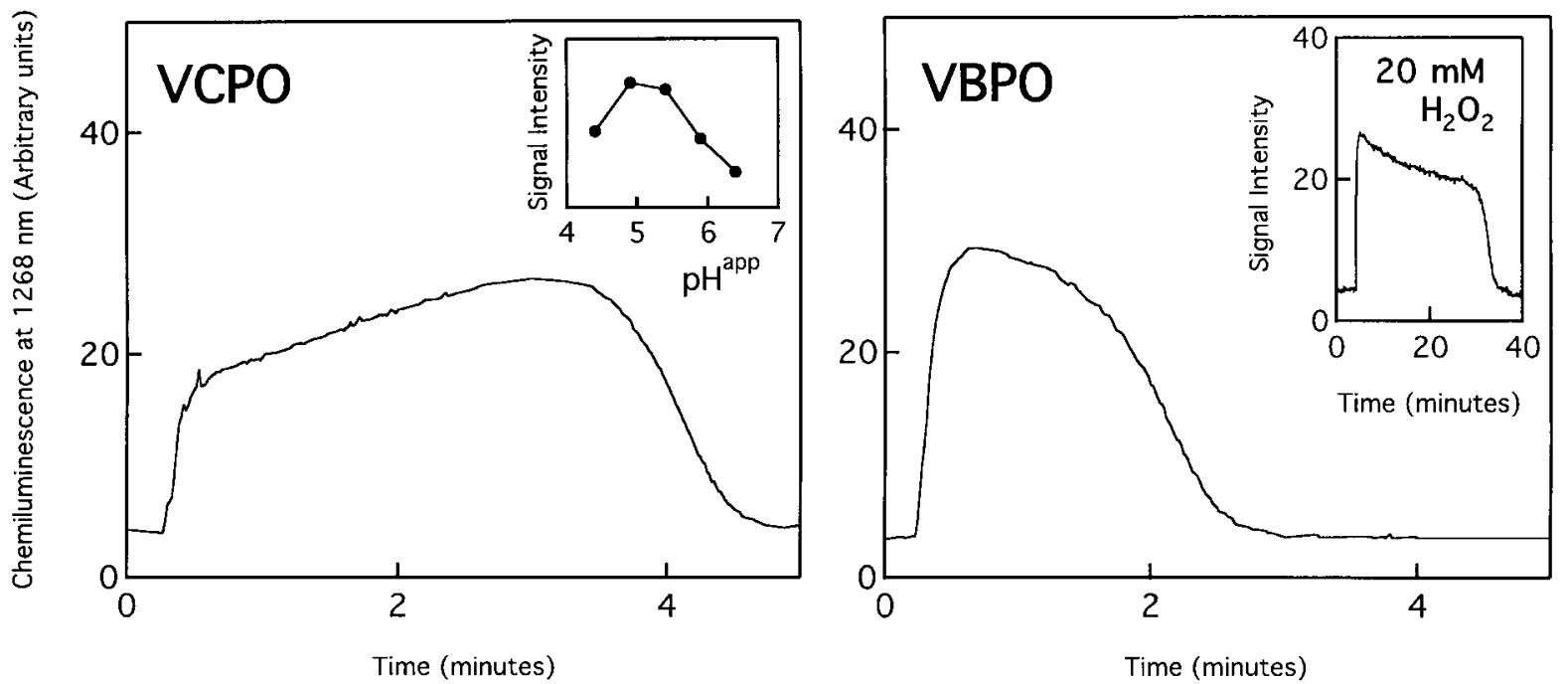

Figure 2. Chemiluminescence from singlet oxygen as produced by vanadium chloroperoxidase (left) and vanadium bromoperoxidase (right). Left panel: $100 \mathrm{nM}$ VCPO, $20 \mathrm{mM}$ citrate/citric acid buffer $\mathrm{pH}^{\text {app }} 5.4,0.5 \mathrm{mM} \mathrm{Br}^{-}, \sim 98 \% \mathrm{D}_{2} \mathrm{O}$. The reaction was started by addition of $2 \mathrm{mM} \mathrm{H}_{2} \mathrm{O}_{2}$. Inset: Apparent $\mathrm{pH}$ optimum for singlet oxygen production by vanadium chloroperoxidase. Conditions $100 \mathrm{nM}$ VCPO, $5 \mathrm{mM} \mathrm{H}_{2} \mathrm{O}_{2}, 0.5 \mathrm{mM} \mathrm{Br}^{-}$, $98 \% \mathrm{D}_{2} \mathrm{O}, 20 \mathrm{mM}$ buffer (acetic acid/NaOH for $\mathrm{pH}$ 4.4, 4.9 and 5.4, MES/NaOH for $\mathrm{pH}^{\text {app }} 5.9$ and 6.4). Right panel: $100 \mathrm{nM}$ VBPO, $20 \mathrm{mM}$ MES/NaOH buffer $\mathrm{pH}^{\text {app }} 6.4,100 \mathrm{mM}^{2}$ $\mathrm{Br}^{-}, \sim 98 \% \mathrm{D}_{2} \mathrm{O}$. The reaction was started by addition of $2 \mathrm{mM} \mathrm{H}_{2} \mathrm{O}_{2}$. The inset shows VBPO at $20 \mathrm{mM} \mathrm{H}_{2} \mathrm{O}_{2}$. 
Table 1. Effect of histidine on the $1268 \mathrm{~nm}$ emission from ${ }^{1} \mathrm{O}_{2}$ and on the bromination of monochlorodimedone.

\begin{tabular}{lll}
\hline & $\begin{array}{l}1268 \mathrm{~nm} \\
\text { emission }^{[\mathrm{a}]}\end{array}$ & $\begin{array}{l}\text { MCD } \\
\text { bromination }^{[\mathrm{b}]}\end{array}$ \\
\hline VCPO Control & + & + \\
$+4 \mathrm{mM}$ histidine & - & +
\end{tabular}

[a] Conditions: $100 \mathrm{nM}$ VCPO, $20 \mathrm{mM}$ citrate buffer $\mathrm{pH}^{\text {app }}$ $5.4,0.5 \mathrm{mM} \mathrm{Br}^{-}, \sim 98 \% \mathrm{D}_{2} \mathrm{O}$. The reaction was started by addition of $50 \mathrm{mM} \mathrm{H}_{2} \mathrm{O}_{2}$. After 2 minutes $4 \mathrm{mM}$ histidine was added.

[b] Conditions: $1 \mathrm{nM}$ VCPO, $20 \mathrm{mM}$ citrate buffer $\mathrm{pH} 5.0$, $0.5 \mathrm{mM} \mathrm{Br}^{-}, 50 \mu \mathrm{M}$ monochlorodimedone The reaction was started by addition of $50 \mathrm{mM} \mathrm{H}_{2} \mathrm{O}_{2}$. After 2 minutes $4 \mathrm{mM}$ histidine was added.

the $\mathrm{pH}$ optimum for ${ }^{1} \mathrm{O}_{2}$ measurements and halide oxidation measurements indicates that the kinetic constants $\left(\mathrm{K}_{\mathrm{M}}\right.$ and $\left.\mathrm{V}_{\max }\right)$ for $\mathrm{H}_{2} \mathrm{O}_{2}$ and the halide substrates are identical. The magnitude of the activity for both the VCPO and the VBPO catalysts (using bromide as cocatalyst) are in the order of $1.0-2.0 \times 10^{2} \mathrm{~s}^{-1}$ (molecules of $\mathrm{H}_{2} \mathrm{O}_{2}$ consumed per molecule catalyst per second) $)^{[35]}$, which is about 1.1-2.2 $\times 10^{4}$ times higher than for the non-enzymatic molybdate catalyst at its optimal $\mathrm{pH},{ }^{[37]}$ illustrating the efficiency of this biological catalyst.

To fully ensure that the chemiluminescence signal was due to ${ }^{1} \mathrm{O}_{2}$ additional control experiments were carried out. An effective quencher of chemiluminescence produced by singlet oxygen is histidine ${ }^{[18,38]}$ and when $4 \mathrm{mM}$ of histidine was added during measurement of the $1268 \mathrm{~nm}$ emission, the signal was immediately quenched (Table 1). Under the same conditions, histidine hardly inhibits the bromination of monochlorodimedone (Table 1), indicating that the quenching of the signal is not due to enzyme inhibition.

Moreover, in Figure 3 it is shown that the chemiluminescence signal was 20-fold lower in an $\mathrm{H}_{2} \mathrm{O}$-containing buffer as compared to the same experiment in a $\mathrm{D}_{2} \mathrm{O}$ containing buffer, in agreement with the 17 times longer lifetime of ${ }^{1} \mathrm{O}_{2}$ in $\mathrm{D}_{2} \mathrm{O}$ than in $\mathrm{H}_{2} \mathrm{O}^{\left[{ }^{39]}\right.}$ No chemiluminescence signal was observed in the absence of either enzyme, halide or peroxide, indicating that all components are essential.

As expected from the bromide turnover numbers of these enzymes, ${ }^{[35]}$ the signals of singlet oxygen production for VCPO and VBPO are similar in intensity, however as mentioned before, VCPO shows an increase of signal in time whereas the VBPO is slowly inactivated. For VCPO the type of buffer used influenced the shape of the trace somewhat but essentially the activation remained. The origin of this slow signal increase therefore remains unclear. From an application point of view it is important that the VCPO is stable against a (starting) concentration of $500 \mathrm{mM} \mathrm{H}_{2} \mathrm{O}_{2}$ and that it remains fully active for at least 1 hour of continuously producing singlet oxygen (Figure 4).

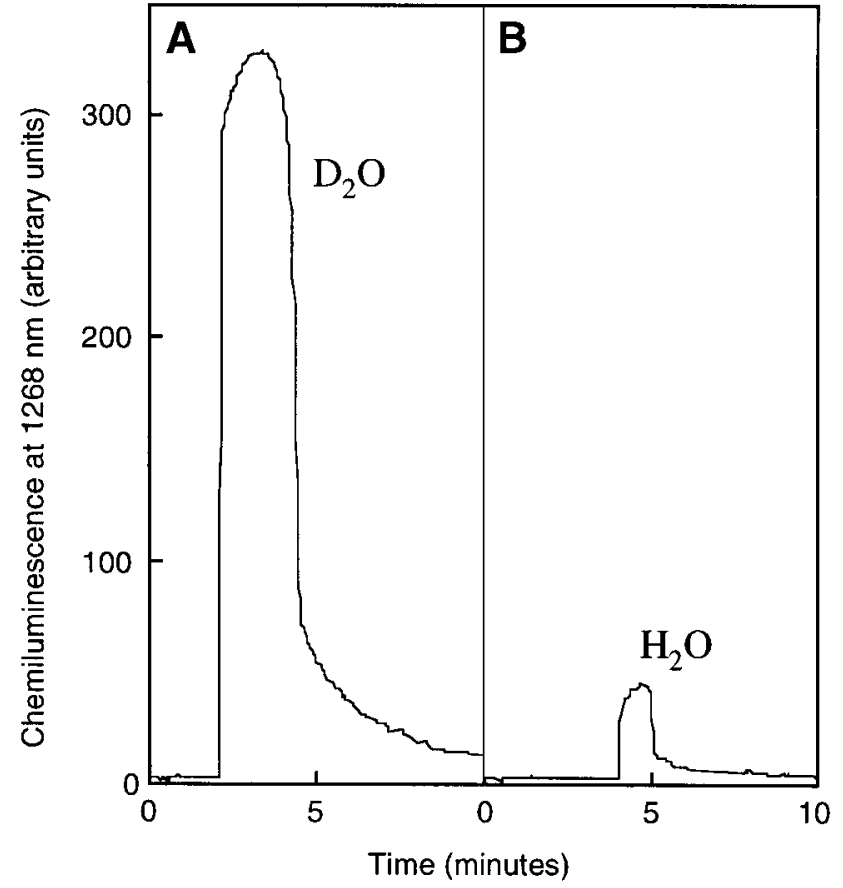

Figure 3. Comparison of chemiluminescence from singlet oxygen produced by vanadium chloroperoxidase in $\mathrm{D}_{2} \mathrm{O}$ and $\mathrm{H}_{2} \mathrm{O}$. Conditions: $500 \mathrm{nM}$ enzyme, $0.5 \mathrm{mM} \mathrm{Br}{ }^{-}$, reaction started by $20 \mathrm{mM} \mathrm{H} \mathrm{O}_{2}$. Panel A: Buffer in $\mathrm{D}_{2} \mathrm{O}(20 \mathrm{mM}$ acetic acid/ $\left.\mathrm{NaOH} \mathrm{pH}^{\text {app }} 5.4, \sim 98 \% \mathrm{D}_{2} \mathrm{O}\right)$. Panel $\mathbf{B}$ : Buffer in $\mathrm{H}_{2} \mathrm{O}(20 \mathrm{mM}$ acetic acid/ $\mathrm{NaOH} \mathrm{pH}$ 5.0). The buffers were made by 50 times dilution of the same $1 \mathrm{M}$ stock solution.

This stability towards both high concentrations of $\mathrm{H}_{2} \mathrm{O}_{2}$ and ${ }^{1} \mathrm{O}_{2}$ is in strong contrast to that of the hemecontaining haloperoxidases.

The production of ${ }^{1} \mathrm{O}_{2}$ by VCPO via the cocatalyst chloride was also tested. Because the conversion rate of chloride is 5 times slower than that for bromide, a lower ${ }^{1} \mathrm{O}_{2}$ production rate is expected. ${ }^{1} \mathrm{O}_{2}$ is indeed produced at a 5 times lower rate, which is still $2.2 \times 10^{3}$ times higher than for peroxomolybdate $\left(5 \mathrm{mM} \mathrm{Cl}^{-}\right.$and $0.5 \mathrm{mM} \mathrm{Br}^{-}$ were used, respectively, which are known to be well above the $\mathrm{K}_{\mathrm{M}}$ values for the halogenating activity of $\mathrm{VCPO}^{[35]}$ and thus saturating the ${ }^{1} \mathrm{O}_{2}$ production rate). This results again confirms that the catalytic halide oxidation, Equation (1), is the rate-determining step.

\section{Inactivation of VCPO at Very Low $\mathrm{H}_{2} \mathrm{O}_{2}$}

The ${ }^{1} \mathrm{O}_{2}$ release by VBPO is similar to that published before:;18] multiple aliquots of $2 \mathrm{mM} \mathrm{H}_{2} \mathrm{O}_{2}$ can be converted into ${ }^{1} \mathrm{O}_{2}$ (inset of Figure 5). In strong contrast to this, $\mathrm{VCPO}$ is not able to convert multiple aliquots of $2 \mathrm{mM} \mathrm{H}_{2} \mathrm{O}_{2}$ without being inactivated (Figure 5), but it converts amounts such as $20 \mathrm{mM} \mathrm{H} \mathrm{H}_{2} \mathrm{O}_{2}$ into ${ }^{1} \mathrm{O}_{2}$ while easily remaining fully active (Figure 3 ). Figure 5 shows that if a second aliquot of $\mathrm{H}_{2} \mathrm{O}_{2}$ is added to the reac- 


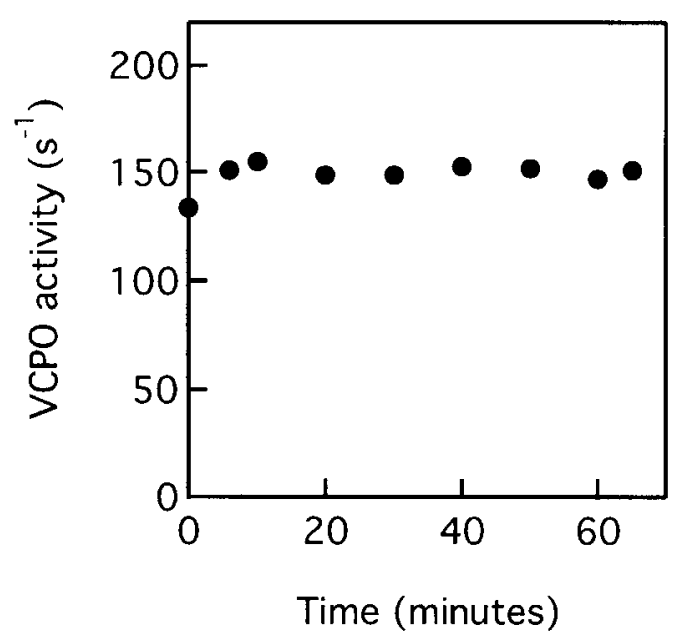

Figure 4. Stability of vanadium chloroperoxidase against $500 \mathrm{mM} \mathrm{H}_{2} \mathrm{O}_{2}$ and a continuous flow of ${ }^{1} \mathrm{O}_{2}$. In a $1-\mathrm{mL}$ reaction mixture ${ }^{1} \mathrm{O}_{2}$ was continuously produced $(200 \mathrm{nM}$ VCPO, $500 \mathrm{mM} \mathrm{H} \mathrm{O}_{2}, 5 \mathrm{mM} \mathrm{Cl}^{-}, 100 \mathrm{mM}$ citrate $\mathrm{pH}$ 5.5). The solution was continuously stirred. From this mixture $25 \mu \mathrm{L}$ aliquots were taken and enzyme activity was tested in $1 \mathrm{~mL}$ of monochlorodimedone assay mixture $(100 \mathrm{mM}$ acetic acid/ $\mathrm{NaOH} \mathrm{pH} 5.0,50 \mu \mathrm{M}$ monochlorodimedone, $0.5 \mathrm{mM}$ $\mathrm{Br}^{-}, 100 \mu \mathrm{M}$ vanadate, $13.5 \mathrm{mM} \mathrm{H}_{2} \mathrm{O}_{2}$ ).

tion mixture after consumption of the first aliquot, mainly a short intense burst of singlet oxygen is observed. After a third aliquot of $\mathrm{H}_{2} \mathrm{O}_{2}$ almost no ${ }^{1} \mathrm{O}_{2}$ formation is observed indicating that the enzyme is inactivated.

An explanation for this phenomenon may be found in the extreme affinity of VCPO for $\mathrm{H}_{2} \mathrm{O}_{2}$, as compared to VBPO ${ }^{[35]}$ Due to this VCPO is still producing $\mathrm{HOBr}$ at maximal rate at $\mathrm{H}_{2} \mathrm{O}_{2}$ concentrations as low as $10-$ $100 \mu \mathrm{M}$. It is conceivable that at a certain point the $\mathrm{H}_{2} \mathrm{O}_{2}$ concentration becomes so low that the nonenzymatic reaction of $\mathrm{H}_{2} \mathrm{O}_{2}$ with $\mathrm{HOBr}$ hardly occurs. Consequently, there is a build-up of a relatively large concentration of $\mathrm{HOBr}$, when nearly all the $\mathrm{H}_{2} \mathrm{O}_{2}$ is converted. This rationalizes both the intense burst of ${ }^{1} \mathrm{O}_{2}$ upon addition of the second aliquot of $\mathrm{H}_{2} \mathrm{O}_{2}$ as well as the inactivation of VCPO. The inactivation could, in principle, be caused by $\mathrm{HOBr}$ itself or by intermediates of the reaction between $\mathrm{HOBr}$ and ${ }^{1} \mathrm{O}_{2}$ during the burst. Inactivation of VCPO by the HOX product itself would be somewhat surprising, as it was previously publish$\mathrm{ed}^{[27]}$ that VCPO is stable towards $\mathrm{HOCl}$ under turnover conditions. However, unpublished results performed by us show that $\mathrm{HOCl}$ in that experiment $(\sim 4 \mathrm{mM})$ in fact reacted with citrate buffer and therefore a reaction product of citrate with $\mathrm{HOCl}$ rather than $\mathrm{HOCl}$ itself is present. In all experiments reported in the literature potential scavengers of $\mathrm{HOX}$ are present (such as $\mathrm{H}_{2} \mathrm{O}_{2}$, buffer, monochlorodimedone or dyes on the surface of the protein; these dyes are not found on the recombinant protein). We tested the resistance of VCPO towards

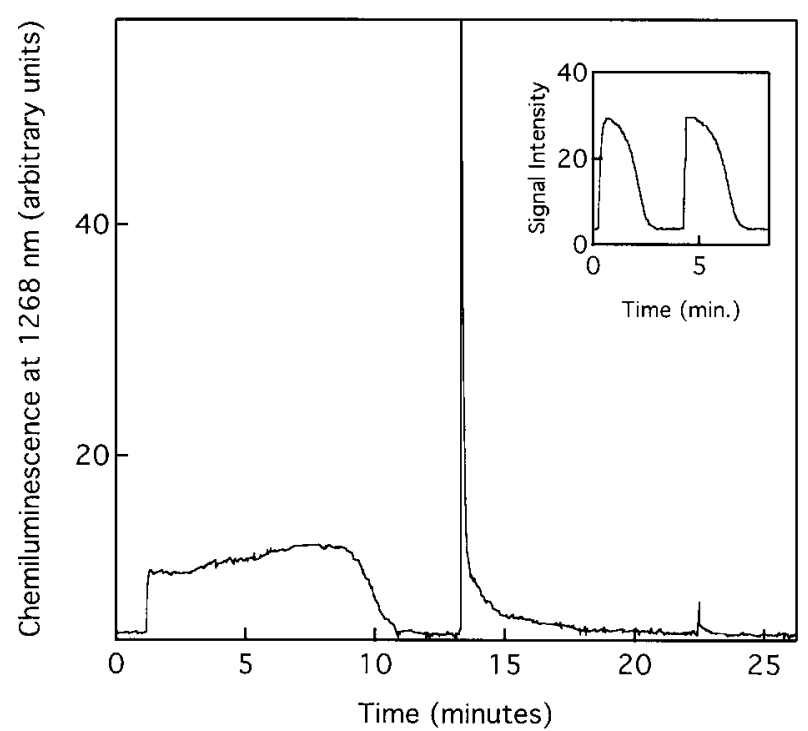

Figure 5. Turnover of multiple aliquots of $\mathrm{H}_{2} \mathrm{O}_{2}$ by vanadium chloroperoxidase. Conditions: $50 \mathrm{nM}$ VCPO, $20 \mathrm{mM}$ citrate/ citric acid $\mathrm{pH}^{\text {app }} 5.4\left(\sim 98 \% \mathrm{D}_{2} \mathrm{O}\right), 0.5 \mathrm{mM} \mathrm{Br}^{-}$. The reaction was started by addition of $2 \mathrm{mM} \mathrm{H}_{2} \mathrm{O}_{2}$. The second aliquot of $\mathrm{H}_{2} \mathrm{O}_{2}$ was added after 13 minutes and the third after 22.5 minutes. Inset: Similar experiment using vanadium bromoperoxidase. $100 \mathrm{nM}$ VBPO, $20 \mathrm{mM} \mathrm{MES} / \mathrm{NaOH}$ buffer $\mathrm{pH}^{\text {app }}$ $6.4,100 \mathrm{mM} \mathrm{Br}^{-}, \sim 98 \% \mathrm{D}_{2} \mathrm{O}$, reaction started by addition of $2 \mathrm{mM} \mathrm{H}_{2} \mathrm{O}_{2}$. The second aliquot of $\mathrm{H}_{2} \mathrm{O}_{2}$ was added after 4.5 minutes.

$\mathrm{HOBr}$ by mixing VCPO $(9 \mathrm{nM})$ with chemically produced $\mathrm{HOBr}(10 \mu \mathrm{M})$ under the same conditions as Figure 5 (for details, see Experimental Section). Normal activity was observed, excluding inactivation of native $\mathrm{VCPO}$ by HOBr. In principle, it is still possible that the inactivation as observed in Figure 5 is caused by interaction of an enzyme intermediate with $\mathrm{HOBr}$ during turnover (at low $\mathrm{H}_{2} \mathrm{O}_{2}$ concentration), however, we did not further investigate the origin of the inactivation since it is not relevant for the application of VCPO as a singlet oxygen catalyst as long as the $\mathrm{H}_{2} \mathrm{O}_{2}$ concentration is kept high.

\section{Chemical Trapping of VCPO/Halide-Generated $\mathrm{H}_{2} \mathrm{O}_{2}$}

Chemical trapping of VCPO/halide-generated singlet oxygen was studied by adding anthracene-9,10-bis(ethanesulphonate), a water-soluble anthracene derivative that is known to react with singlet oxygen ${ }^{[40,41]}$ forming an endoperoxide (Scheme 2).

This conversion can be easily monitored by ${ }^{1} \mathrm{H}$ NMR; reactions were carried out directly within NMR tubes and followed in time. Figure 6 shows the ${ }^{1} \mathrm{H}$ NMR data of the conversion induced by VCPO, both with chloride and bromide as cocatalyst. 
<smiles>O=[Se]CCc1c2ccccc2c(CCC(=O)O)c2ccccc12</smiles>

Scheme 2. Reaction of anthracene-9,10-bis(ethanesulphonate) with singlet oxygen.

Panel A shows the spectrum of the starting compound anthracene-9,10-bis(ethanesulphonate). With chloride as cocatalyst (panel B) anthracene-9,10-bis(ethane- sulphonate) is completely converted into the corresponding endoperoxide. Side product formation from the $\mathrm{HOCl}$ intermediate with anthracene-9,10-bis(ethanesulphonate) is not observed. The small signal at $3.60 \mathrm{ppm}$ in both the starting compound and product spectrum originates from Tris-buffer (in which the enzyme is routinely stored), as was confirmed by taking an NMR spectrum of $1 \mathrm{mM}$ Tris under identical conditions (not shown). It should be noted that the chloride is substoichiometric with respect to anthracene-9,10-bis(ethanesulphonate), confirming the catalytic role of the halide. The spectrum obtained for the product is identical to panel $\mathbf{C}$, which corresponds to the endoperoxide formed by molybdate released ${ }^{1} \mathrm{O}_{2} \cdot{ }^{[42]}$

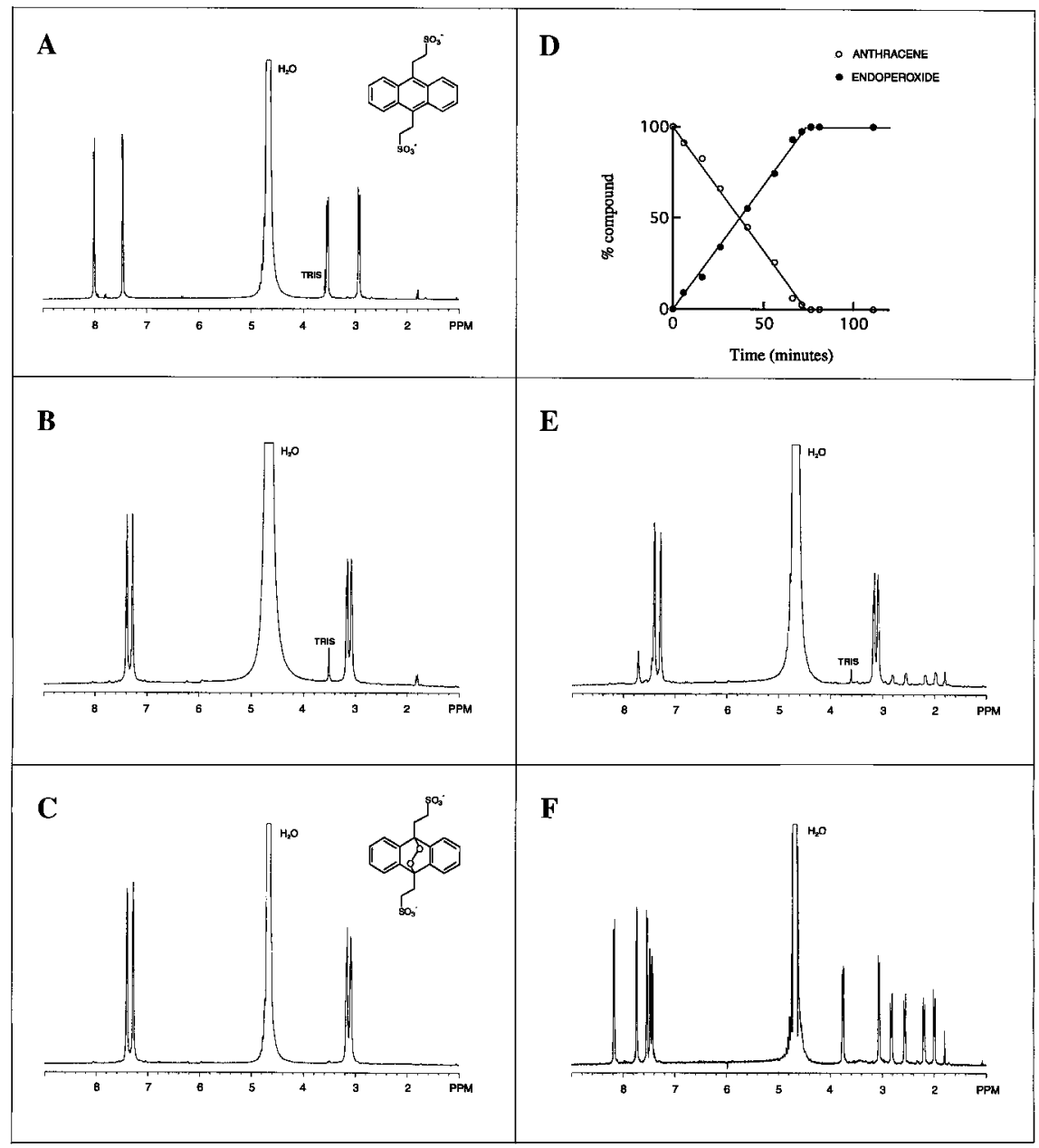

Figure 6. In situ conversion of anthracene-9,10-bis(ethanesulphonate) into the corresponding endoperoxide by vanadium chloroperoxidase, with either chloride or bromide as co-catalyst, as followed by ${ }^{1} \mathrm{H}$ NMR. A: $10 \mathrm{mM}$ anthracene-9,10bis(ethanesulphonate), $400 \mathrm{nM}$ VCPO, $200 \mathrm{mM} \mathrm{H} \mathrm{H}_{2}, 100 \mathrm{mM} \mathrm{CD} \mathrm{O}_{3} \mathrm{COOD} / \mathrm{NaOD}$ buffer $\left(\mathrm{pH}^{\mathrm{a} p p} 5.4\right), \sim 99 \% \mathrm{D}_{2} \mathrm{O}$. B: Corresponding endoperoxide, formed 80 minutes after addition of the cocatalyst chloride $(5 \mathrm{mM})$. C: Corresponding endoperoxide formed from $10 \mathrm{mM}$ anthracene-9,10-bis(ethanesulphonate) by peroxomolybdate under alkaline conditions

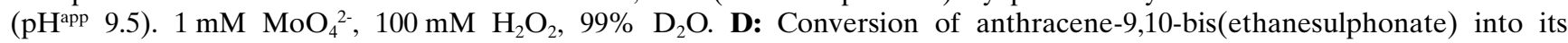
corresponding endoperoxide by VCPO as a function of time as calculated from integration of the NMR signals. $\bigcirc$ Anthracene9,10-bis(ethanesulphonate), - corresponding endoperoxide. E: Corresponding endoperoxide formed 120 minutes after addition of the cocatalyst bromide $(0.5 \mathrm{mM})$. Starting conditions identical as in A, but $50 \mathrm{nM} \mathrm{VCPO}$. F: $10 \mathrm{mM}$ anthracene9,10-bis(ethanesulphonate) was mixed with $5 \mathrm{mM} \mathrm{HOBr}$ (see Experimental Section) in the absence of $\mathrm{H}_{2} \mathrm{O}_{2} .100 \mathrm{mM}$ $\mathrm{CD}_{3} \mathrm{COOD} / \mathrm{NaOD}$ buffer ( $\mathrm{pH}^{\text {app }} 5.4$ ), 99\% $\mathrm{D}_{2} \mathrm{O}$. 
Table 2. Catalysts for $\mathrm{H}_{2} \mathrm{O}_{2}$ disproportionation to ${ }^{1} \mathrm{O}_{2}$ in aqueous environment.

\begin{tabular}{|c|c|c|c|c|c|}
\hline Catalyst system & $\mathrm{Na}_{2} \mathrm{MoO}_{4}^{[7]}$ & $\begin{array}{l}\mathrm{La}\left(\mathrm{NO}_{3}\right)_{3} / \mathrm{NaOH} \\
1 / 2^{[8]}\end{array}$ & $\mathrm{VCPO}^{[\mathrm{a}]}$ & $\mathrm{VBPO}^{[\mathrm{b}]}$ & Heme $\mathrm{CPO}^{[\mathrm{c}]}$ \\
\hline $\mathrm{pH}$ range & $7.0-12.5$ & $5.0-12.5$ & $3.0-6.0$ & $3.0-7.0$ & $2.5-5.0$ \\
\hline Cocatalyst & none & none & $\begin{array}{l}\mathrm{Cl}^{-}(5 \mathrm{mM}) \text { or } \\
\mathrm{Br}^{-}(0.5 \mathrm{mM})\end{array}$ & $\begin{array}{l}\mathrm{Cl}^{-}(1000 \mathrm{mM}) \text { or } \\
\mathrm{Br}^{-}(100 \mathrm{mM})\end{array}$ & $\mathrm{Cl}^{-}(20 \mathrm{mM})$ \\
\hline Turnover $\mathrm{H}_{2} \mathrm{O}_{2}$ & $0.01 \mathrm{~s}^{-1}$ & $0.005 \mathrm{~s}^{-1}$ & $\begin{array}{l}20 \mathrm{~s}^{-1}\left(\mathrm{Cl}^{-}\right) \\
100 \mathrm{~s}^{-1}\left(\mathrm{Br}^{-}\right)\end{array}$ & $\begin{array}{l}0.6 \mathrm{~s}^{-1}\left(\mathrm{Cl}^{-}\right) \\
200 \mathrm{~s}^{-1}\left(\mathrm{Br}^{-}\right)\end{array}$ & $\begin{array}{l}1200 \mathrm{~s}^{-1} \text { (only in- } \\
\text { itially) }\end{array}$ \\
\hline $\begin{array}{l}{ }^{1} \mathrm{O}_{2} \text { yield from } \\
\mathrm{H}_{2} \mathrm{O}_{2} \text { in water }\end{array}$ & $100 \%$ & $45 \%$ & $100 \%^{[\mathrm{d}]}\left(\mathrm{Cl}^{-}\right)$ & $80 \%{ }^{[\mathrm{e}]}\left(\mathrm{Br}^{-}\right)$ & $100 \%{ }^{[\mathrm{d}]}\left(\mathrm{Cl}^{-}\right)$ \\
\hline $\begin{array}{l}\text { Oxidative stabili- } \\
\text { ty }\end{array}$ & $\begin{array}{l}\text { stable inorganic } \\
\text { system }\end{array}$ & $\begin{array}{l}\text { stable inorganic } \\
\text { system }\end{array}$ & $\begin{array}{l}\text { stable for at least } \\
25,000 \text { turnovers; } \\
\max 1.0 \mathrm{M} \mathrm{H}_{2} \mathrm{O}_{2} \\
\text { tolerated }\end{array}$ & $\begin{array}{l}\text { slow inactivation; } \\
\text { max } 0.1 \mathrm{M} \mathrm{H}_{2} \mathrm{O}_{2} \\
\text { tolerated }\end{array}$ & $\begin{array}{l}\text { fast inactivation } \\
\text { already at } \sim 0.002 \\
\mathrm{M} \mathrm{H}_{2} \mathrm{O}_{2}\end{array}$ \\
\hline $\begin{array}{l}\text { Organic synthetic } \\
\text { scope }\end{array}$ & $\begin{array}{l}\text { broad, but sub- } \\
\text { strate must be in- } \\
\text { ert toward perox- } \\
\text { omolybdate, thus } \\
\text { excluding i.a. } \\
\text { allylic alcohols } \\
\text { and alkenyl } \\
\text { amines }\end{array}$ & $\begin{array}{l}\text { very broad, in- } \\
\text { cluding allylic al- } \\
\text { cohols and alke- } \\
\text { nyl amines }\end{array}$ & $\begin{array}{l}\text { alkenes excluded } \\
\text { that react effi- } \\
\text { ciently with } \\
\mathrm{HOCl} \text { (in compe- } \\
\text { tition with } \mathrm{H}_{2} \mathrm{O}_{2} \text { ) }\end{array}$ & $\begin{array}{l}\text { alkenes excluded } \\
\text { that react effi- } \\
\text { ciently with } \\
\mathrm{HOBr} \text { (in com- } \\
\text { petition with } \\
\mathrm{H}_{2} \mathrm{O}_{2} \text { ) }\end{array}$ & $\begin{array}{l}\text { almost none due } \\
\text { to inactivation }\end{array}$ \\
\hline
\end{tabular}

[a] Vanadium chloroperoxidase from the fungus $C$. inaequalis, recombinantly expressed in the yeast $S$. cerevisiae. ${ }^{[35]}$

[b] Vanadium bromoperoxidase from the seaweed $A$. nodosum. ${ }^{[36,43]}$

[c] Heme-containing chloroperoxidase from the mold C. fumago. ${ }^{[44,45]}$

[d] ${ }^{1} \mathrm{O}_{2}$ yield for the reaction of $\mathrm{HOCl}$ with $\mathrm{H}_{2} \mathrm{O}_{2}$.

[e] ${ }^{1} \mathrm{O}_{2}$ yield for the reaction of $\mathrm{HOBr}$ with $\mathrm{H}_{2} \mathrm{O}_{2}$.

Line broadening in the product spectra of panels $\mathbf{B}$ and C as compared to that of the starting compound spectrum in panel $\mathbf{A}$ is due to formation of oxygen within the NMR tubes. In panel $\mathbf{D}$ the time dependence of product formation catalysed by VCPO and substrate disappearance is depicted and a clear linearity is observed. From this linearity it can be concluded that the enzyme remains stable during the process. When instead of chloride, bromide is used as a cocatalyst in the enzymatic conversion about $20 \%$ of the anthracene9,10-bis(ethanesulphonate) is converted into another product (panel $\mathbf{E}$ ). This may be due a different reactivity of the $\mathrm{HOCl}$ formed versus $\mathrm{HOBr}$ towards $\mathrm{H}_{2} \mathrm{O}_{2}$ or towards anthracene-9,10-bis(ethanesulphonate) or a combination of both. Generally $\mathrm{HOCl}$ reacts more effectively with $\mathrm{H}_{2} \mathrm{O}_{2}$ than $\mathrm{HOBr} \cdot{ }^{[14]}$ Therefore we assume that the enzymatically produced $\mathrm{HOCl}$ is fully scavenged by the high concentration of $\mathrm{H}_{2} \mathrm{O}_{2}$ whereas under the reaction conditions used part of the $\mathrm{HOBr}$ reacts with anthracene-9,10-bis(ethanesulphonate) instead of with $\mathrm{H}_{2} \mathrm{O}_{2}$. To test whether the observed side product is indeed due to reaction of $\mathrm{HOBr}$ with anthracene-9,10-bis(ethanesulphonate), $10 \mathrm{mM}$ anthracene-9,10-bis(ethanesulphonate) was mixed with $5 \mathrm{mM}$ $\mathrm{HOBr}$ in the absence of $\mathrm{H}_{2} \mathrm{O}_{2}$ (panel $\left.\mathbf{F}\right)$. About $3.5 \mathrm{mM}$ product is formed with very similar chemical shifts as the side product observed in panel $\mathbf{E}$. The exact nature of the side product was not further investigated, but the presence of four different $\mathrm{CH}_{2}$ resonances suggests a loss of symmetry due to aryl bromination.

In Table 2 we compare the properties of five different catalysts for ${ }^{1} \mathrm{O}_{2}$-production by $\mathrm{H}_{2} \mathrm{O}_{2}$ disproportionation in aqueous environment.

Table 2 demonstrates that VCPO is much more active (three to four orders of magnitude) than the inorganic molybdate and lanthanum systems. However, there are limitations with respect to its usefulness in preparative "dark" singlet oxygenations. Its scope is limited to substrates that are less reactive towards $\mathrm{HOCl}$ than $\mathrm{H}_{2} \mathrm{O}_{2}$ and this requirement excludes many alkenes.

\section{Conclusion}

In summary, we have shown that vanadium chloroperoxidase from $C$. inaequalis is a very effective singlet oxygen catalyst under mildly acidic conditions and is very stable towards $\mathrm{H}_{2} \mathrm{O}_{2}$ and singlet oxygen under turnover conditions. Its $\mathrm{pH}$ optimum is around 5.0. A potential drawback of this enzymatic system may be the formation of side products as a result of a reaction of the substrate or product with the hypohalous acid inter- 
mediate. However, we have shown that it is possible to cleanly convert a typical singlet oxygen trap using chloride as the co-catalyst. During the conversion of this trap the enzymatic system remains fully active for more than one hour. The clean conversion upon the use of the cocatalyst chloride and the high stability versus singlet oxygen make VCPO superior to VBPO from $A$. nodosum. VBPO can in principle also catalyse the oxidation of $\mathrm{Cl}^{-}$, however at a 36-fold lower rate ${ }^{[43]}$ and at a very high $\mathrm{Cl}^{-}$concentration $(\sim 1.0 \mathrm{M})$. Although VCPO has been shown to be superior to VBPO, each substrate should be tested for side reactions since each individual substrate may have a different reactivity towards the $\mathrm{HOCl}$ intermediate. Since effectively a competition exists between $\mathrm{H}_{2} \mathrm{O}_{2}$ and the substrate for $\mathrm{HOCl}$, the $\mathrm{H}_{2} \mathrm{O}_{2}$ concentration should be kept high during the application. If this concentration is kept high, the observed inactivation of the enzyme at very low $\mathrm{H}_{2} \mathrm{O}_{2}$ concentrations will not occur. $10 \mathrm{mM}$ anthracene-9,10bis(ethanesulphonate) was converted by $400 \mathrm{nM}$ VCPO catalyst $(25,000$ turnovers) within 75 minutes, corresponding to a turnover frequency of $5.6 \mathrm{~s}^{-1}$. The production of the $\mathrm{HOCl}$ intermediate is maximally $20 \mathrm{~s}^{-1},{ }^{35]}$ which means that under these conditions part of the singlet oxygen is physically quenched before it can react with the anthracene molecule. However, this is a satisfying efficiency which may be increased using a higher anthracene concentration. Also changing the target molecule will affect this efficiency. In $\mathrm{H}_{2} \mathrm{O}$ this efficiency will be lower due to physical quenching of ${ }^{1} \mathrm{O}_{2}$, but even then from an application point of view a very good conversion rate will be obtained as compared with the inorganic molybdate and lanthanum systems. In addition, these systems are not effective at such low $\mathrm{pH}$ values. These features make the enzyme system an interesting additional tool in the box of singlet oxygen catalysts.

\section{Experimental Section}

\section{Chemiluminescence Detector}

The luminescence originating from ${ }^{1} \mathrm{O}_{2}$ at $1268 \mathrm{~nm}$ was detected by an $\mathrm{N}_{2}$-cooled $\mathrm{Ge}$-diode detector from North Coast Scientific Corp., Model EO-817L, connected to a lock-in amplifier from Stanford Research Systems Model SR830 DSP. The detector was powered by a North Coast Scientific Corp. Model Bias Supply Model 823A. The geometry of the setup ${ }^{[37}$ was kept constant for all experiments. Experiments were performed in a 3-mL sample cell. For experimental details, see figure legends.

\section{${ }^{1}$ H NMR Spectroscopy}

Spectra were recorded on a $500 \mathrm{MHz}$ Varian Inova NMR spectrometer. Reactions were carried out within the NMR tubes. A little hole was made in the plastic cap of the NMR tube to release excess oxygen.

\section{Activity Measurements}

The oxidation of bromide by VCPO in the absence and presence of histidine was measured in an assay containing monochlorodimedone (MCD). Upon bromination or chlorination by the hypohalous acid formed by the VCPO a loss of absorption is observed $\left(\Delta \varepsilon_{290 \mathrm{~nm}}=20 \mathrm{mM}^{-1} \mathrm{~cm}^{-1}\right){ }^{[46]}$

\section{Chemicals}

Sodium hypochlorite was purchased from Acros organics as a $5 \%$ solution (in chlorine), corresponding to $0.70 \mathrm{M} \mathrm{ClO}^{-}$. The concentration of $\mathrm{ClO}^{-}$was checked by titration of a monochlorodimedone solution $\left(\varepsilon_{290 \mathrm{~nm}}=20.2 \mathrm{mM}^{-1} \mathrm{~cm}^{-1}\right)$, which is converted into dichlorodimedone $\left(\varepsilon_{290 \mathrm{~nm}}=0.2 \mathrm{mM}^{-1} \mathrm{~cm}^{-1}\right)$. A $400 \mathrm{mM} \mathrm{BrO}^{-}$stock solution was made by mixing $\mathrm{ClO}^{-}$with $\mathrm{Br}^{-}$. At $\mathrm{pH} 7-9$, this $\mathrm{ClO}^{-}$is known to react very fast with $\mathrm{Br}^{-}$ to give $\mathrm{BrO}^{-}$and $\mathrm{Cl}^{-}{ }^{[47]}$ This stock was made freshly and used within one minute. A slight excess of $10 \mathrm{mM} \mathrm{Br}^{-}$was used to ensure full conversion of the $\mathrm{ClO}^{-}$. A drawback of this excess $\mathrm{Br}^{-}$could be reaction with $\mathrm{BrO}^{-}$to form $\mathrm{Br}_{2}$ and $\mathrm{Br}_{3}^{-}$, however, upon further dilution of the " $\mathrm{BrO}^{-}$" stock, $\mathrm{BrO}^{-}$is the main component and the contributions of $\mathrm{Br}_{2}$ and $\mathrm{Br}_{3}{ }^{-}$ become minimal. ${ }^{[47]}$

The synthesis of the sodium salt of anthracene-9,10-bis(ethanesulphonate) was described previously. ${ }^{[40,41,42]}$

\section{Buffers}

Buffers used for chemiluminescence measurements were prepared by dilution of $1.0 \mathrm{M}$ stock solutions $\left(\mathrm{H}_{2} \mathrm{O}\right.$ based $)$ in $\mathrm{D}_{2} \mathrm{O}$ giving an $\mathrm{H}_{2} \mathrm{O}$ contribution of about $2 \%$ to the reaction mixtures. In the final experiments the $\mathrm{H}_{2} \mathrm{O}$ content is slightly higher than $2 \%$ due to contributions from $\mathrm{H}_{2} \mathrm{O}_{2}$ and enzyme stocks. In accordance with the literature the resulting buffers give an apparent $\mathrm{pH}\left(\mathrm{pH}^{\mathrm{app}}\right)$, which is about $0.4 \mathrm{pH}$ units higher than the stock due to the $\mathrm{D}_{2} \mathrm{O} \cdot{ }^{[48,49]}$ In the ${ }^{1} \mathrm{H}$ NMR experiments the presence of protons was minimised by using a deuterated buffer ( > 99 atom \% D). A $1.0 \mathrm{M}$ stock solution of $\mathrm{CD}_{3} \mathrm{COOD}$ in $\mathrm{D}_{2} \mathrm{O}$ was adjusted to $\mathrm{pH}^{\text {app }} 5.4$ with an $\mathrm{NaOD}$ solution in $\mathrm{D}_{2} \mathrm{O}$ and further diluted with $\mathrm{D}_{2} \mathrm{O}$ for the experiments.

\section{Enzymes}

Vanadium chloroperoxidase from the fungus Curvularia inaequalis was recombinantly expressed in the yeast Saccharomyces cerevisiae and purified as described before. ${ }^{[35]}$ The turnover frequency (molecules of substrate converted per second per molecule of catalyst) of this enzyme is about $100 \mathrm{~s}^{-1}$ with respect to bromide $\left(0.5 \mathrm{mM} \mathrm{Br}^{-}, \mathrm{pH} 5.0,2 \mathrm{mM} \mathrm{H}_{2} \mathrm{O}_{2}\right.$, at $25^{\circ} \mathrm{C}$, monochlorodimedone assay) and $20 \mathrm{~s}^{-1}$ with respect to chloride $\left(5 \mathrm{~m} \mathrm{M} \mathrm{Cl}^{-}\right.$, pH 5.0, $2 \mathrm{mM} \mathrm{H}_{2} \mathrm{O}_{2}$, at $25^{\circ} \mathrm{C}$, monochlorodimedone assay). Vanadium bromoperoxidase from the seaweed Ascophyllum nodosum was purified as described before. ${ }^{[50]}$ The turnover frequency of this catalyst is about $120 \mathrm{~s}^{-1}$ at $\mathrm{pH}$ 6.0,100 $\mathrm{mM} \mathrm{Br}^{-}, 2 \mathrm{mM} \mathrm{H}_{2} \mathrm{O}_{2}$, at $25^{\circ} \mathrm{C}$. Both enzymes are 
standardly stored in $100 \mathrm{mM}^{\text {TrisSO}} \mathrm{S}_{4}$ buffer $\mathrm{pH} 8.3$ containing $100 \mu \mathrm{M}$ vanadate.

\section{VCPO Inactivation Test}

Freshly prepared $4.0 \mathrm{mM} \mathrm{HOBr}$ stock (diluted from the $400 \mathrm{mM}$ stock which was described above) was added to $2.5 \mathrm{~mL}$ reaction mixture containing $20 \mathrm{mM}$ citrate $\mathrm{pH} 5.0$ and $18 \mathrm{nM}$ VCPO to a final concentration of $10 \mu \mathrm{M}$. After 4 minutes of incubation the activity of VCPO was tested by addition of $100 \mu \mathrm{M}$ monochlorodimedone, $0.5 \mathrm{mM} \mathrm{Br}^{-}$and $1 \mathrm{mM} \mathrm{H}_{2} \mathrm{O}_{2}$.

\section{Acknowledgements}

Dr. Véronique Nardello and Pr. Jean Marko are kindly thanked for their help during the chemiluminescence experiments, $M r$. Jan Geenevasen and Ms. Lidy van der Burg for their help during the NMR experiments. This research was supported by the Council of Chemical Sciences of the Netherlands Organisation for Scientific Research and was made possible by financial support of DSM Fine Chemicals (The Netherlands).

\section{References}

[1] E. L. Clennan, Tetrahedron 2000 56, 9151 -9179.

[2] J. M. Aubry, in Membrane Lipid Oxidation, Vol. II. (Ed.: C. Vigo-Pelfrey), CRC Press, Boca Raton, 1991.

[3] B. Sels, Thesis, Katholieke Universiteit Leuven, Agricultural and Applied Biological Sciences, Leuven; 2000, pp. $37-40$.

[4] I. Rosenthal, in Singlet Oxygen, Vol. 1. (Ed.: A. A. Frimer), CRC Press, Boca Raton, 1985.

[5] C. Pierlot, J. M. Aubry, K. Briviba, H. Sies, P. Dimascio, in Methods in Enzymology, (Eds.: L. Packer, H. Sies), Academic Press, 2000, Vol. 319, pp. 3-20.

[6] A. M. Held, D. J. Halko, J. Am. Chem. Soc. 1978 100, $5732-5740$.

[7] V. Nardello, J. Marko, G. Vermeersch, J. M. Aubry, Inorg. Chem. 1995 34, 4950-4957.

[8] V. Nardello, J. Barbillat, J. Marko, P. T. Witte, P. L. Alsters, J. M. Aubry, Chem. Eur. J. 2003, accepted.

[9] R. C. Allen, R. J. Stjernholm, R. H. Steele, Biochem. Biophys. Res. Commun. 1972 47, 679-684.

[10] R. C. Allen, Biochem. Biophys. Res. Comm. 1975 63, $675-683$.

[11] R. C. Allen, Biochem. Biophys. Res. Comm. 1975 63, $684-691$.

[12] J. Piatt, P. J. O’Brien, Eur. J. Biochem. 1979 93, 323-332.

[13] J. R. Kanofsky, J. Biol. Chem. 1983 258, 5991-5993.

[14] J. R. Kanofsky, J. Biol. Chem. 1984 259, 5596-5600.

[15] J. R. Kanofsky, H. Hoogland, R. Wever, S. J. Weiss, J. Biol. Chem. 1988 263, 9692-9696.

[16] J. R. Kanofsky, Chem.-Biol. Interac. 1989 70, 1-28.

[17] J. R. Kanofsky, in Peroxidases in Chemistry and Biology, Vol. II, (Eds.: J. Everse, K. E. Everse, M. B. Grisham), CRC Press, Boca Raton, 1990, pp. 219-237.
[18] R. R. Everett, J. R. Kanofsky, A. Butler, J. Biol. Chem. $1990265,4908-4914$.

[19] R. R. Everett, H. S. Soedjak, A. Butler J. Biol. Chem. $1990265,15671-15679$.

[20] A. Messerschmidt, R. Wever, Proc. Natl. Acad. Sci. USA 1996 93, 392-396.

[21] A. Messerschmidt, L. Prade, R. Wever, Biol. Chem. 1997 378, 309-315.

[22] M. Weyand, H. J. Hecht, M. Kies, M. F. Liaud, H. Vilter, D. J. Schomburg, J. Mol. Biol. 1999 293, 595-611.

[23] M. N. Isupov, A. R. Dalby, A. A. Brindley, Y. Izumi, T. Tanabe, G. N. Murshudiv, J. A. Littlechild, J. Mol. Biol. 2000 299, $1035-1049$.

[24] P. J. Kraulis, J. Appl. Cryst. 1991 24, 946-950.

[25] R. Renirie, W. Hemrika, S. R. Piersma, R. Wever, Biochemistry 2000 39, $1133-1141$.

[26] E. de Boer, H. Plat, M. G. M. Tromp, M. C. R. Franssen, H. C. van der Plas, E. M. Meijer, H. E. Schoemaker, R. Wever, Biotechnol. Bioeng. 1987 30, 607-610.

[27] J. W. P. M. van Schijndel, P. Barnett, J. Roelse, E. G. M. Vollenbroek, R. Wever, Eur. J. Biochem. 1994 225, 151 157.

[28] M. Andersson, A. Willets, S. Allenmark, J. Org. Chem. 1997 62, 8455-8458.

[29] H. B. ten Brink, A. Tuynman, H. L. Dekker, W. Hemrika, Y. Izumi, T. Oshiro, H. E. Schoemaker, R. Wever, Inorg. Chem. 1998 37, 6780-6784.

[30] H. B. ten Brink, H. L. Holland, H. E. Schoemaker, H. van Lingen, R. Wever, Tetrahedron Asymmetry 1999 10, $4563-4572$.

[31] H. B. ten Brink, H. E. Schoemaker, R. Wever, Eur. J. Biochem. 2001 268, 132-138.

[32] H. S. Soedjak, J. V. Walker, A. Butler, Biochemistry 1995 34, 12689-12696.

[33] G. E. Meister, Winter, A. Butler, Biochemistry 1996 35, $11805-11811$

[34] R. Wever, W. Hemrika, in Handbook of Metalloproteins, (Eds.: A. Messerschmidt, R. Huber, T. Poulos, K. Wieghardt), John Wiley \& Sons, Ltd., Chichester, 2001, pp $1417-1428$.

[35] W. Hemrika, R. Renirie, S. Macedo-Ribeiro, A. Messerschmidt, R. Wever, J. Biol. Chem. 1999 274, 23820 23827.

[36] E. de Boer, R. Wever, J. Biol. Chem. 1988 263, $12326-$ 12332.

[37] J. M. Aubry, B. Cazin, Inorg. Chem. 1988 27, 2013-2014.

[38] C. S. Foote, in Singlet oxygen, (Eds.: H. H. Wasserman, R. W. Murray), Academic Press, Orlando, 1979, pp 139171.

[39] F. Wilkinson, W. P. Helman, A. B. Ross, J. Phys. Chem. Ref Data 1995 24, 663-1021.

[40] M. Botsivali, D. F. Evans, J. Chem. Soc. Chem. Commun. 1979, 1114-1116.

[41] D. F. Evans, M. W. Upton, J. Chem. Soc. Dalton Trans. 1985, $1141-1145$.

[42] V. Rataj-Nardello, I. Bulduk, A. H. M. de Vries, P. Johnston, J. M. Aubry, P. L. Alsters, manuscript in preparation. 
[43] H. S. Soedjak, A. Butler, Inorg. Chem. 1990 29, $5015-$ 5017.

[44] D. R. Morris, L. P. Hager, J. Biol. Chem. 1966 241, 1763 1768.

[45] G. P. Rai, S. Sakai, A. M. Florez, L. Mogollon, L. P. Hager, Adv. Synth. Catal. 2001, 343, 638-645.

[46] L. P. Hager, D. R. Morris, F. S. Brown, H. Eberwein, J. Biol. Chem. 1966 241, 1769-1777.
[47] M. Lewin, in Bromine and its compounds, (Ed.: E. E. Jolles), Ernest Benn Limited, London, 1966, p. 703.

[48] P. K. Glasoe, F. A. Long, J. Phys. Chem. 1960 64, 188.

[49] A. K. Covington, M. Paabo, R. A. Robinson, R. G. Bates, Anal. Chem. 1968 40, 700-706.

[50] R. Wever, H. Plat, E. de Boer, Biochim. Biophys. Act. $1985830,181-186$. 